\title{
Spinal protein kinase $A$ and phosphorylated extracellular signal-regulated kinase signaling are involved in the antinociceptive effect of phytohormone abscisic acid in rats
}

\begin{abstract}
A proteína quinase A da medula espinhal e a sinalização da quinase fosforilada regulada por sinal extracelular estão envolvidas no efeito antinociceptivo do ácido fito-hormônio abscísico em ratos
\end{abstract} Mahtab MOLLASHAHI', Mehdi ABBASNEJAD ${ }^{1,2}$, Saeed ESMAEILI-MAHANI ${ }^{1}$

\begin{abstract}
Objective: The phytohormone abscisic acid (ABA) as a signaling molecule exists in various types of organisms from early multicellular to animal cells and tissues. It has been demonstrated that ABA has an antinociceptive effect in rodents. The present study was designed to assess the possible role of PKA and phosphorylated ERK ( $p$-ERK) on the antinociceptive effects of intrathecal (i.t.) ABA in male Wistar rats. Methods: The animals were cannulated intrathecally and divided into different experimental groups ( $n=6-7)$ : Control (no surgery), vehicle (received ABA vehicle), ABA-treated groups (received ABA in doses of 10 or $20 \mu \mathrm{g} / \mathrm{rat}$ ), ABA plus H.89 (PKA inhibitor)-treated group which received the inhibitor 15 min prior to the ABA injection. Tail-flick and hot-plate tests were used as acute nociceptive stimulators to assess ABA analgesic effects. p-ERK was evaluated in the dorsal portion of the spinal cord using immunoblotting. Results: Data showed that a microinjection of ABA (10 and $20 \mu \mathrm{g} / \mathrm{rat}$, i.t.) significantly increased the nociceptive threshold in tail flick and hot plate tests. The application of PKA inhibitor (H.89, $100 \mathrm{nM} / \mathrm{rat}$ ) significantly inhibited ABA-induced analgesic effects. Expression of $\mathrm{p}$-ERK was significantly decreased in ABA-injected animals, which were not observed in the ABA+H.89-treated group. Conclusions: Overall, i.t. administration of ABA (10 $\mu$ / rat) induced analgesia and p-ERK down-expression likely by involving the PKA-dependent mechanism.
\end{abstract}

Keywords: abscisic acid; anti-nociception; PKA; p-ERK; rats.

RESUMO

Objetivo: O ácido fito-hormônio abscísico (ABA) existe como molécula sinalizadora em vários tipos de organismos, de multicelulares a células e tecidos animais. Foi demonstrado que o ABA tem efeito antinociceptivo em roedores. 0 presente estudo foi desenhado para avaliar o possivel papel da PKA e da ERK fosforilada (p-ERK) nos efeitos antinociceptivos do ABA intratecal (i.t.) em ratos Wistar machos. Métodos: Os animais foram canulados por via i.t. e divididos em diferentes grupos experimentais $(n=6-7)$ : controle (sem cirurgia), veículo (veículo ABA recebido), grupos tratados com ABA (recebeu ABA em doses de 10 ou 20 mg/rato), grupo tratado com ABA mais H.89 (inibidor de PKA) que recebeu o inibidor 15 minutos antes da injeção de ABA. Os testes de movimento da cauda e placa quente foram utilizados como estimuladores nociceptivos agudos para avaliar os efeitos analgésicos da ABA. A p-ERK foi avaliada na porção dorsal da medula espinhal por imunotransferência. Resultados: A microinjeção de ABA (10 e 20 g/rato, i.t.) aumentou significativamente o limiar nociceptivo nos testes de movimento da cauda e placa quente. A aplicação de inibidor de PKA (H.89, $100 \mathrm{nM} /$ rato) inibiu significativamente os efeitos analgésicos induzidos por ABA. A expressão de p-ERK diminuiu significativamente em animais injetados com ABA que não foram observados no grupo

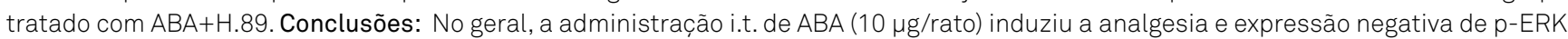
provavelmente envolvendo mecanismo dependente de PKA.

Palavras-chave: ácido abscísico; antinocicepção; PKA; p-ERK; ratos.

\footnotetext{
'Shahid Bahonar University of Kerman, Faculty of Sciences, Department of Biology, Kerman.

${ }^{2}$ Kerman University of Medical Sciences, Kerman Neuroscience Research Center (KNRC), Laboratory of Molecular Neuroscience, Kerman, Iran.

Mahtab MOLLASHAHI (iD https://orcid.org/0000-0002-7427-7454; MehdiABBASNEJAD (iD) https://orcid.org/0000-0001-6024-4507; Saeed ESMAEILIMAHANI (iD) https://orcid.org/0000-0001-5550-9806

Correspondence: Mehdi Abbasnejad; Dept. of Biology, Faculty of Sciences, Shahid Bahonar University of Kerman; Kerman, Iran P.O. Box: 76135-133; E-mail: mabbas@uk.ac.ir

Support: This study was supported by the Kerman Neuroscience Research Center with grant (\#95/26), Kerman University of Medical Sciences.

Conflict of interest: There is no conflict of interest to declare.

Received on June 2, 2019; Received in its final form on August 14, 2019; Accepted on September 5, 2019.
} 
Phytohormone abscisic acid (ABA) is naturally produced by plants and has a very important physiological activities like plants disease resistance and plant response to environmental stressors ${ }^{1,2}$. Production and accumulation of ABA by animal tissues has been reported ${ }^{3}$. Surprisingly, it is endogenously produced by mammalian brain. However, neurobiological effects of this phytoterpenoid have not been fully clarified. ABA is involved in numerous biological activities, such as migration, the release of anti-inflammatory cytokines, glucose homeostasis, stem cell expansion and, also, the control of inflammatory and immune responses ${ }^{4,5}$. Potential antiinflammatory effects of ABA have been reported in inflammatory bowel diseases, atherosclerosis and obesity-related inflammation ${ }^{6-8}$. Plant and animal studies showed that ABA recruits a very wide spectrum of signaling pathways, such as: peroxisome proliferator-activated receptors (PPARs), lanthioninesynthetase C-like protein 2 (LANCL2), and several protein kinase, including PKA, PKC and phosphatidylinositol 3-Kinase ${ }^{9,10}$. Recently, Naderi et al. reported that central microinjection of $\mathrm{ABA}$ improves cognitive functions and exhibits antianxiety effects with PKC and PI3 kinase signaling pathways ${ }^{11}$. ABA-induced insulin releasing effect, as one of the important and remarkable effects of $A B A$, is performed with PKA signaling ${ }^{12}$. We have previously reported that the central administration of ABA elicits antinociceptive effects in rats ${ }^{13}$. However, its detail mechanism is not yet fully elucidated.

It is well known that the spinal cord has an important role in pain transmission, regulation and processing. Specially, dorsal horn parts and laminas, connectivity of the pain first order neurons at spinal cord segments levels with another modality, such as tactile, have crucial responsibilities in pain control and transmission ${ }^{14}$.

In addition, ERK (extracellular signal-regulated kinase) is a family member of mitogen activated protein kinases (MAPKs), which is affected by acute damaging stimulation. Damaging stimulation-induced activation of ERK in spinal neurons contributes to the induction and maintenance of nociceptive pain hypersensitivity ${ }^{15,16}$. Considering that the possible mechanisms of ABA-induced anti-nociception in the spinal cord levels are not yet clarified, this study was designed to evaluate the role of PKA signaling and ERK activity in ABA analgesic effect.

\section{METHODS}

\section{Animal}

Male Wistar rats (230-270 gr) were obtained from the Shahid Bahonar University of Kerman Animal House. The rats were housed under standard conditions $\left(22 \pm 2^{\circ} \mathrm{C}\right.$ with a $12 \mathrm{~h}$ light/dark cycle); food and water were available ad libitum throughout the experiment. After intrathecal (i.t.) cannulating, the rats were transmitted to the animal room and housed separately. Before initiating behavioral experiments, the rats were handled daily, for 4 consecutive days, to adjust them for the manipulation and reduction of nonspecific stress responses. All experiments followed the guidelines on ethical standards for investigation of experimental pain in animals and were approved by the Animal Experimentation Ethics Committee of the Kerman Neuroscience Research Center (EC/KNRC/96).

\section{Drug}

$( \pm)$-Cis,trans-ABA and PKA inhibitor (H.89) were purchased from Sigma-Aldrich (USA). ABA was dissolved in dimethyl sulfoxide (DMSO), then diluted with artificial cerebrospinal fluid (aCSF). The ratio of aCSF to DMSO was 2:1 (v/v). PKA inhibitor was dissolved in distilled water. These drugs were given in the volume of $10 \mu \mathrm{l}$ (i.t.).

\section{Experimental designs}

Rats were randomly divided into five experimental groups (n=6-7). Control group (Cont), which had no surgery and treatment; vehicle-treated group (Veh), which received ABA vehicle; $A B A-t r e a t e d$ groups, different doses of $A B A$ (10 or $20 \mu \mathrm{g} / \mathrm{rat}$ ) were intrathecally administrated. ABA plus H.89treated group $(\mathrm{H} .89+\mathrm{ABA})$ were treated with $100 \mathrm{nM} /$ rat H.89 15 min prior to $\mathrm{ABA}$ injection.

\section{Intrathecal catheterization protocol}

The technique of spinal catheterization was carried out on anesthetized rats using intraperitoneal injection of ketamine and xylazine (50 and $5 \mathrm{mg} / \mathrm{kg}$, respectively). In this method, PE10 polyethylene tubing was inserted in each rat, according to a previously published method ${ }^{17}$. Following intrathecal cannulation, rats showed neuronal disturbances, which were discarded from behavioral experiments. All animals were killed after the behavioral tests and their dissected lumbar spinal cords were transferred to liquid nitrogen for molecular study.

\section{Tail flick test}

The radiant heat analgesiometer as an apparatus for measuring central analgesic activity of drugs was used. The base part of the tails of the rats were located on a radiant heat source and the reaction time (the latency to withdrawal of the tail) was verified. The average value of three measurements was considered and used in the analysis. The mean baseline latencies obtained by calculating predrug was recorded three times. The cut-off time was fixed at $15 \mathrm{~s}$ to avoid any damage to the tail. After assessing the baseline threshold, rats were injected with the drugs and the reaction time was determined at varying times after drug injection. Tail-withdrawal latencies were expressed by mean to the percentage of antinociception, according to the following formula: \%Antinociception (\%MPE)=(reaction time of test-basal reaction time)/(cut-off time-basal reaction time) $)^{*} 100$. 


\section{Hot plate}

The hot plate test was used to measure the effectiveness of analgesics. Rats were individually retained on a metal surface at a stable temperature $\left(52 \pm 2^{\circ} \mathrm{C}\right)$ and baseline nociceptive behaviors were recorded. To prevent tissue damage, $30 \mathrm{~s}$ cut-off time was considered. After drug injection, nociceptive behaviors (licking, lifting, or jumping) were recorded as post- drug latency responses: $30,45,60,90,120,180$, and 230 min after the drug treatments. The following formula was used to calculate the maximum possible effect (MPE): \%MPE=(latency after drug administration-baseline latency)/ (cut-off time-baseline latency)* 100 .

\section{Western blot}

Rat spinal cord tissues were lysed in RIPA buffer, comprising $10 \mathrm{mM}$ Tris- $\mathrm{HCl}, \mathrm{pH} 7.4,150 \mathrm{mM} \mathrm{NaCl}, 1 \mathrm{Mm}$ ethylenediaminetetraacetic acid, $0.1 \%$ sodium dodecyl sulfate $0.1 \%$ Nadeoxycholate, $1 \%$ NP-401\% NP-40 and protease inhibitors (1 mM phenylmethylsulfonyl fluoride, $2.5 \mu \mathrm{g} / \mathrm{mL}$ of leupeptin, $10 \mu \mathrm{g} / \mathrm{mL}$ of aprotinin) and $1 \mathrm{mM}$ sodium orthovanadate. The same volumes of protein from samples $(40 \mu \mathrm{g})$ were separated using sodium dodecyl sulfate polyacrylamide gel electrophoresis and moved to a polyvinyl difluoride membrane. Blots were then blocked with $3 \%$ nonfat milk in $0.1 \%$ TweenTris-buffered saline for two hours at room temperature, followed by overnight $\left(4^{\circ} \mathrm{C}\right)$ incubation with p-ERK primary antibody (1:1000) (Santa Cruz, USA). The primary antibody was detected with goat anti mouse horseradish peroxidaseconjugated secondary antibody $(1: 15,000)$ (Santa Cruz, USA) for $60 \mathrm{~min}$, at room temperature. The antibody-antigen complexes were identified using the ECL system and exposed to Lumi-Film chemiluminescent detection film. Image J software was used to evaluate the intensity of the blotting bands.
GAPDH $(1: 10,000)$ immunoblot was used as loading control. The expression values were presented as tested proteins/ GAPDH ratio for each rat.

\section{Statistical analysis}

Statistical Package for the Social Sciences (SPSS), version 19, was used. The results are expressed as mean \pm S.E.M. Significant differences in \%MPE (antinociception) between groups over the times of the study were examined using one or, in some cases, two-way analysis of variance (ANOVA) followed by the Tukey's test. Values $<0.05$ were considered statistically significant.

\section{RESULTS}

\section{Tail flick test}

ABA potentials to modulate thermal nociceptive threshold was assessed by tail flick apparatus. As shown in Figure 1A, the microinjection of ABA (10 and $20 \mu \mathrm{g} /$ rat, i.t.) significantly increased tail flick nociceptive threshold when compared to the control group. ABA vehicle injection had no effects on the nociceptive threshold. Intrathecal microinjection of $10 \mu \mathrm{g}$ ABA increased the mean of latency time 30 min after injection, which had a peak $45 \mathrm{~min}$ after injection and terminated at 120 min. In addition, $20 \mu \mathrm{g}$ ABA induced antinociception, beginning 45 min after the injection ( $\mathrm{p}<0.001)$, then decreased gradually until $120 \mathrm{~min}$ (Figure 1A). Besides that, to explore the involvement of PKA signaling on ABA anti-nociceptive effect, H.89 (100 nM), a PKA inhibitor, was administrated $15 \mathrm{~min}$ prior to ABA $(10 \mu \mathrm{g} / \mathrm{rat})$. Results showed that prior treatment of H.89 (100 nM) was able to inhibit ABA- induced analgesic effect during the time course of tail flick test (Figure 1B).
A

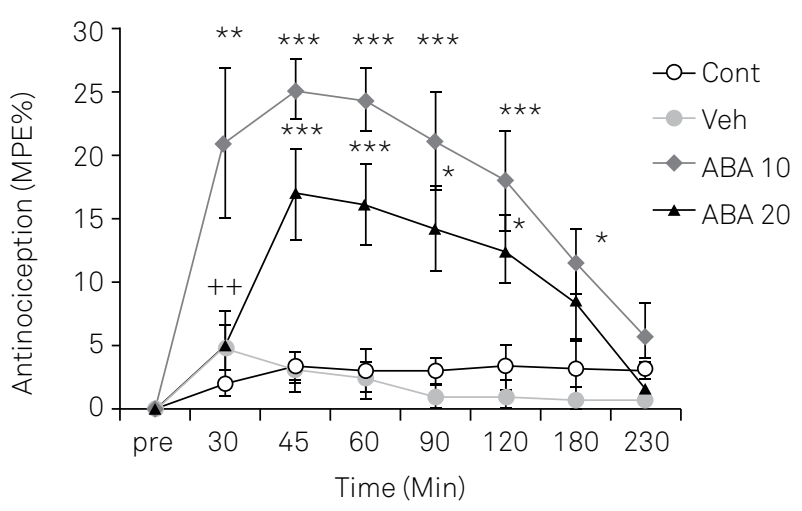

B

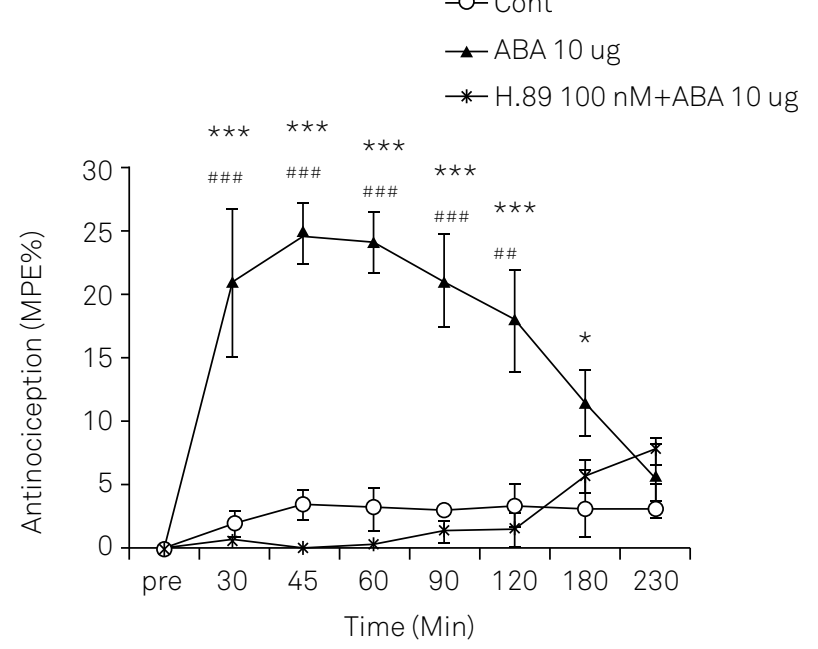

${ }^{*} p<0.05,{ }^{*} p<0.01$, and ${ }^{* * *} p<0.001$ as compared with the control group at the same time. $++p<0.01$ as compared with $10 \mu g$ ABA in the same time. \#\#p<0.01 and \#\#\#p<0.001 as compared with H.89+ABA injected rats in same time. ABA: abscisic acid, H.89: protein kinase A inhibitor.

Figure 1. The antinociceptive effect of abscisic acid (ABA 10 and $15 \mu \mathrm{g} / \mathrm{rat}$ ) in the tail-flick test (A) and the effect of pre-

administration of $\mathrm{H} .89$ (100 nM/rat, i.t.), on the analgesic effect of $10 \mu g \mathrm{ABA}(\mathrm{B})$. Values represent mean \pm SEM ( $\mathrm{n}=7$ rats per group). 


\section{Hot plate test}

Hot plate latency was measured to a further evaluation of ABA aptitude for modulating nociception induced by heat stimuli. Results indicated that i.t. administration of ABA at 10 and $20 \mu \mathrm{g}$ significantly decreased nociceptive threshold in comparison with either the control or vehicle groups. ABA (10 and $20 \mu \mathrm{g}$ ) significantly caused an analgesic effect at $30 \mathrm{~min}$ after the beginning of the test $(\mathrm{p}<0.001)$. Moreover, data showed that 10 and $20 \mu \mathrm{g}$ ABA-related analgesia persisted up to $45 \mathrm{~min}$ (Figure 2A). However, pretreatment i.t. administration of $\mathrm{H} .89$ (100 nM) significantly inhibited ABA $(10 \mu \mathrm{g})$ increased the mean of latency time in the hot plate test (Figure 2B). These findings showed that ABA analgesic effects might be mediated with PKA activities.

\section{Western blot}

In the present study, the western blot analysis was performed to assess the effect of i.t. administration of either ABA $(10 \mu \mathrm{g})$ or H.89 (100 nM), plus ABA (10 $\mu \mathrm{g})$ on p-ERK expression in the lumbar spinal, following acute thermal stimulation. Results showed that i.t. administration of ABA at $20 \mu \mathrm{g}$ could significantly increase the spinal level of p-ERK. However, the down regulatory effect $\mathrm{ABA}$ on $\mathrm{p}$-ERK expression was inhibited by H.89 (100 nM) as PKA inhibitor (Figure 3). It suggests that ABA inhibitory effect on p-ERK expression could be achieved by the modulation of PKA signaling.

\section{DISCUSSION}

Natural plant chemical compounds as new medical agents possess considerable properties for the control and relief of pain ${ }^{18}$.The present investigation was designed to assess the

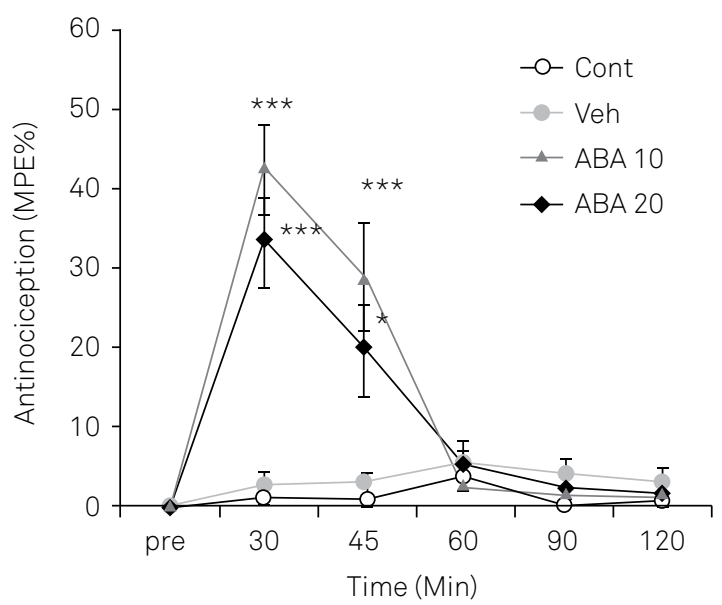

possible antinociceptive effects of phytohormone ABA and its possible molecular mechanism in the spinal cord level using tail flick and hot plate tests. Data revealed that intrathecal microinjection of ABA elicited antinociceptive effects, which was blocked by the PKA inhibitor. In addition, the results showed that microinjection of analgesic doses of ABA could
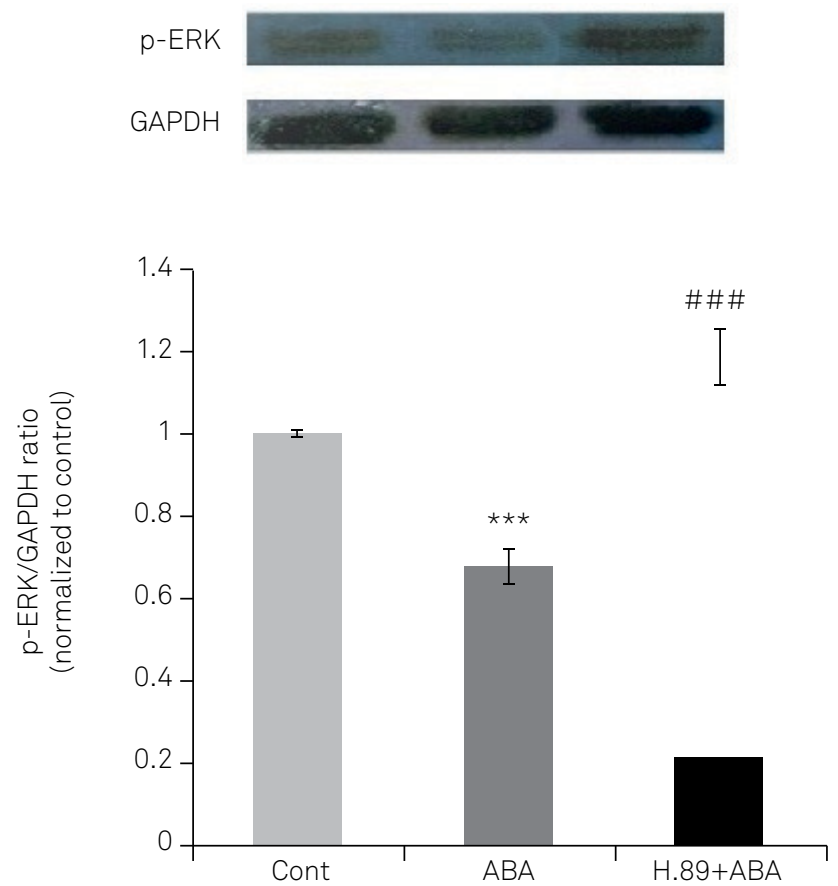

$\star * \star p<0.001$ indicating the significant differences with the control group. $\# \# \# p<0.001$ indicating the significant differences with the ABA-treated animals. ABA: abscisic acid.

Figure 3. The effects of abscisic acid (ABA, $10 \mu \mathrm{g} / \mathrm{rat}$ ) and ABA plus PKA inhibitor (H.89, $100 \mathrm{nM} /$ rat) on the spinal cord $\mathrm{p}$-ERK. GAPDH was used as an internal control. Data were shown as meantS.E.M.
B

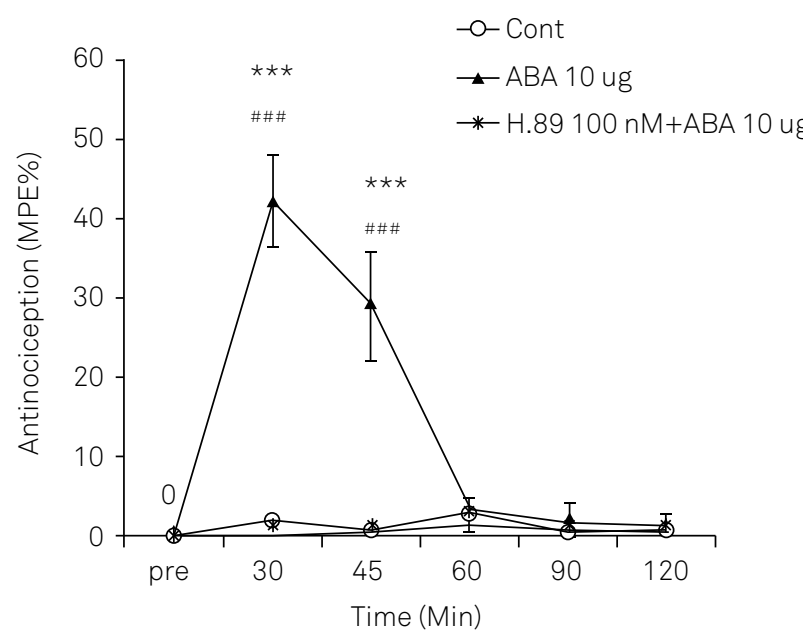

${ }^{*} p<0.05,{ }^{* *} p<0.01$, and ${ }^{* * *} p<0.001$ as compared with the control group in the same time. \#\#\#p<0.001 as compared with H.89+ABA injected rats in the same time. ABA: abscisic acid, H.89: protein kinase A inhibitor

Figure 2. The antinociceptive effect of abscisic acid (ABA 10 and $15 \mu \mathrm{g} / \mathrm{rat}$ ) in the hot plate test (A) and the effect of preadministration of H.89 (100 nM/rat, i.t.), on the analgesic effect of $10 \mu \mathrm{g} A B A(B)$. Values represent mean \pm SEM ( $n=7$ rats per group). 
decrease the lumbar spinal levels of p-ERK. To support that, it has been previously reported that the central administration of ABA was able to increase thermal nociception threshold in both the tail flick and the hot plate, whereas it could decrease formalin-induced inflammation in rats ${ }^{13}$.

Our data showed that ABA analgesic effect was accompanying p-ERK's down expression in the spinal cord. Numerous studies confirmed that there is a relation between $\mathrm{p}$-ERK and neural stimulation in spinal neurons and glia $^{19,20}$. The reduction of nociception was proved to be closely associated with the expressions of several signal transduction molecules, such as p-ERK in the spinal cords of mice $^{21}$. In addition, Park et al. reported that the antinociceptive effect of oxyntomodulin appears to be partly mediated by the reduction of $\mathrm{p}$-ERK level in the spinal cord ${ }^{22}$. Besides that, the inhibition of neuronal p-ERK expression was able to suppress acute abdominal pain ${ }^{23}$. Moreover, Cruz et al. reported that pharmacological blockade of ERK phosphorylation in the spinal cord could attenuate nociceptive behaviors in monoarthritic rats ${ }^{24}$. Thus, pharmacological research using ERK blockers would be useful to define the mechanism underlying $\mathrm{ABA}$ analgesic effects.

ABA signaling pathway in animals' species, such as hydroid and sponges, stimulate target cell increasing the cAMP concentration and PKA activity ${ }^{25,26}$. Moreover, PKA contributes in the signaling pathway of $\mathrm{ABA}$ in murine and human pancreatic $\beta$-cells so that the application of PKA inhibitor can suppress the ABA-stimulated insulin secretion in pancreatic $\beta$-cells ${ }^{12}$.

PKA plays an important role in amplifying the production of some neuropeptides and regulates their gene expres$\operatorname{sion}^{27}$. It has been indicated that the gene expression and secretion of MET-enkephaline, a pain modulatory neuropeptide, is regulated by $\mathrm{PKA}^{28}$. MET-enkephaline binds to respective receptors regions modulating nociception, opioid receptors, which are positioned on nerve fibers on the injured area and can strongly repress excitatory neurotransmitters release and modulate calcium channel activity in nerve ending ${ }^{29,30}$. Additionally, cAMP/PKA activation induces the release of $\boldsymbol{\alpha}$-MSH in the central nervous system, as an anti-inflammatory neuropeptide, during the inflammatory promoting process ${ }^{31}$. $\alpha$-MSH activity leads to a decrease in producing and releasing chemokine and cytokines, which are involved in inflammation ${ }^{31}$.

PKA is also known as a key target, which modulates synaptic transmissions by inhibitory neurotransmitters.
In vivo studies indicated that PKA has functional roles in regulating glycine currents through the phosphorylating of glycine receptors subunits. Increased PKA activityinduced phosphorylation of glycine receptors subunits in trigeminal as well as spinal neurons after exposure to the damaging stimulations has a fundamental role in the synaptic inhibition control ${ }^{32,33}$. Study results showed that ABA activity in animal tissues lead to the release of glycine ${ }^{34}$. It has been indicated that PKA promotes the expression of GABAA-R subunits in CNS and GABAA-R signaling can regulate other neurotransmitters release from nerve ending, which reduces excitable output from lower spinal cord layer ${ }^{35,36}$. Therefore, in this study, PKA dependent- potentiation of glycine or GABA signaling, at least partially, might be involved in ABA analgesic activity.

In the current study, rats treated with $\mathrm{ABA}(10 \mu \mathrm{g} / \mathrm{rat})$, 30 min after the application, showed a higher tail flick latency in comparison with ABA $(20 \mu \mathrm{g} / \mathrm{rat})$. However, there were no statistically significant differences in reaction to heat stimulus between groups in the rest of the time course experiment. It is already indicated ABA physiological effects are achieved in a concentration-dependent manner ${ }^{11,37}$. Spatially, our last studies indicated that the central microinjection of ABA $(10 \mu \mathrm{g} / \mathrm{rat})$ is enough to improve spatial learning and memory performances and to suppress thermal and inflammatory nociception in adult male rats ${ }^{11,13}$. In the present study, to find the most effective dose of $\mathrm{ABA}$ for preventing nociception, we also administrated $A B A$ $20 \mu \mathrm{g} / \mathrm{rat}$, which surprisingly had no different effects from that of $\mathrm{ABA}$ at the dose $10 \mu \mathrm{g} / \mathrm{rat}$.

Moreover, data showed that ABA $(10 \mu \mathrm{g} / \mathrm{rat})$ analgesic effect was more effectual in the tail flick than in the hot plate test. In experimental settings, both apparatus are widely used to assess thermal nociception; however, there are some structural differences between tests, which could affect the experiments outcome ${ }^{38,39}$. Most importantly, the different heat radiation levels have been used in each test. In addition, the tail flick test evaluates thermal nociception reflex by applying heat radiant to tail, whereas the hot-plate test assesses pain behavior as a result of footpad contact with a heated surface ${ }^{39}$.

In conclusion, our results showed that rat's intrathecal application of $\mathrm{ABA}$ as phytohormone could induce significant analgesic effects and decrease p-ERK expression. The ABA effects were inhibited following pharmacological inhibition of PKA activity.

\section{References}

1. Xiong $L$, Zhu JK. Regulation of abscisic acid biosynthesis. Plant Phys. 2003 Sep;133(1):29-36. https://doi.org/10.1104/pp.103.025395

2. Mauch-Mani B, Mauch F. The role of abscisic acid in plant-pathogen interactions. Curr Opin Plant Biol. 2005 Aug;8(4):409-14. https://doi. org/10.1016/j.pbi.2005.05.015

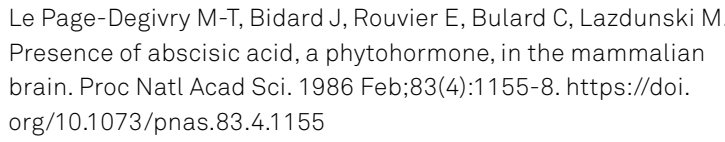

Le Page-Degivry M-T, Bidard J, Rouvier E, Bulard C, Lazdunski M Presence of abscisic acid, a phytohormone, in the mammalian brain. Proc Natl Acad Sci. 1986 Feb;83(4):1155-8. https://doi. org/10.1073/pnas.83.4.1155 
4. Li HH, Hao RL, Wu SS, Guo PC, Chen CJ, Pan LP, et al. Occurrence, function and potential medicinal applications of the phytohormone abscisic acid in animals and humans. Biochem Pharmacol. 1986; 83(4):1155-8. https://doi.org/10.1016/j.bcp.2011.06.042

5. Lievens L, Pollier J, Goossens A, Beyaert R, Staal J. Abscisic acid as pathogen effector and immune regulator. Front Plant Sci. 2017 Apr;8:587. https://doi.org/10.3389/fpls.2017.00587

6. Guri AJ, Hontecillas R, Si H, Liu D, Bassaganya-Riera J. Dietary abscisic acid ameliorates glucose tolerance and obesity-related inflammation in db/db mice fed high-fat diets. Clin Nutr. 2007 Feb;26(1):107-16. https://doi.org/10.1016/j.clnu.2006.07.008.

7. Guri AJ, Misyak SA, Hontecillas R, Hasty A, Liu D, Si H, et al. Abscisic acid ameliorates atherosclerosis by suppressing macrophage and CD4+ T cell recruitment into the aortic wall. J Nutr Biochem. 2010 Dec;21(12):1178-85. https://doi.org/10.1016/j.jnutbio.2009.10.003. PMC2891372

8. Guri AJ, Hontecillas R, Bassaganya-Riera J. Abscisic acid ameliorates experimental IBD by downregulating cellular adhesion molecule expression and suppressing immune cell infiltration. Clin Nutr. 2010 Dec;29(6):824-31. https://doi.org/10.1016/j.clnu.2010.02.009

9. Bassaganya-Riera J, Skoneczka J, Kingston D, Krishnan A, Misyak S, Guri A, et al. Mechanisms of action and medicinal applications of abscisic acid. Curr Med Chem. 2010;17(5):467-78. https://doi. org/10.2174/092986710790226110

10. Bassaganya-Riera J, Guri AJ, Lu P, Climent M, Carbo A, Sobral BW, et al. Abscisic acid regulates inflammation via ligand-binding domainindependent activation of peroxisome proliferator-activated receptor Y.J Biol Chem. 2011 Jan;286(4):2504-16. https://doi.org/10.1074/jbc. M110.160077

11. Naderi R, Esmaeili-Mahani S, Abbasnejad M. Phosphatidylinositol3-kinase and protein kinase $\mathrm{C}$ are involved in the pro-cognitive and anti-anxiety effects of phytohormone abscisic acid in rats. Biomed Pharmacother. 2017 Dec;96:112-9. https://doi.org/10.1016/j. biopha.2017.09.089

12. Bruzzone S, Bodrato N, Usai C, Guida L, Moreschi I, Nano R, et al. Abscisic acid is an endogenous stimulator of insulin release from human pancreatic islets with cyclic ADP ribose as second messenger. J Biol Chem. 2008 Nov;283(47):32188-97. https://doi.org/10.1074/jbc. M802603200

13. Mollashahi M, Abbasnejad M, Esmaeili-Mahani S. Phytohormone abscisic acid elicits antinociceptive effects in rats through the activation of opioid and peroxisome proliferatoractivated receptors beta/delta. Eur J Pharmacol. 2018 Aug;832:75-80. https://doi. org/10.1016/j.ejphar.2018.05.013

14. Alves JM, Lin K. Neuropathic Pain: A Review of Interneuronal Disinhibition. Arch Neurosci. 2018;5(1):e12290. https://doi. org/10.5812/archneurosci.12290

15. Ji R-R, Baba H, Brenner GJ, Woolf CJ. Nociceptive-specific activation of ERK in spinal neurons contributes to pain hypersensitivity. Nat Neurosci. 1999 Dec;2(12):1114-9. https://doi.org/10.1038/16040

16. Galan A, Lopez-Garcia JA, Cervero F, Laird JM. Activation of spinal extracellular signaling-regulated kinase- 1 and -2 by intraplantar carrageenan in rodents. Neurosci Lett. 2002 Mar;322(1):37-40. https://doi.org/10.1016/S0304-3940(02)00078-2

17. Yaksh TL, Rudy TA. Chronic catheterization of spinal ubarachnoid space. Physiol Behav. 1976 Dec;17(6):1031-6. https://doi. org/10.1016/0031-9384(76)90029-9

18. Solomon US, Olugbemide A. Antinociceptive effects of methyl jasmonate in experimental animals. J Nat Med. 2011 Jan;65(34):466-70. https://doi.org/10.1007/s11418-011-0520-3

19. Ma W, Quirion R. Partial sciatic nerve ligation induces increase in the phosphorylation of extracellular signal-regulated kinase (ERK) and C-Jun N-terminal kinase $=(J N K)$ in astrocytes in the lumbar spinal dorsal horn and the gracile nucleus. Pain. 2002 Sep;99(1-2):175-84. https://doi.org/10.1016/s0304-3959(02)00097-0
20. Daulhac L, Mallet C, Courteix C, Etienne M, Duroux E, Privat AM, et al. Diabetes induced mechanical hyperalgesia involves spinal mitogen-activated protein kinase activation in neurons and microglia via N-methyl-D-aspartate-dependent mechanisms. Mol Pharmacol. 2006 Oct;70(4):1246-54. https://doi.org/10.1124/mol.106.025478

21. Jang SP, Park SH, Jung JS, Lee HJ, Hong JW, Lee JY, et al. Characterization of changes of pain behavior and signal transduction system in food-deprived mice. Animal cells and systems. 2018;22(4):227-33. https://doi.org/10.1080/19768354.2018.1490348

22. Park SH, Lee JR, Jang SP, Park SH, Lee HJ, Hong JW, et al. Antinociceptive profiles and mechanisms of centrally administered oxyntomodulin in various mouse pain models Neuropeptides. 2018 Apr;68:7-14. https://doi.org/10.1016/j.npep.2018.01.002

23. Cho IH, Lee MJ, Jang M, Gwak NG, Lee KY, Jung HS. Minocycline markedly reduces acute visceral nociception via inhibiting neuronal ERK phosphorylation. Mol. Pain. 2012;8(1):13. https://doi. org/10.1186/1744-8069-8-13

24. Cruz CD, Neto FL, Castro-Lopes J, et al. Inhibition of ERK phosphorylation decreases nociceptive behaviour in monoarthritic rats. Pain. 2005 Aug;116(3):411-9. https://doi.org/10.1016/j.pain.2005.05.031

25. Zocchi E, Carpaneto A, Cerrano C, Bavestrello G, Giovine M, Bruzzone $\mathrm{S}$, et al. The temperature-signaling cascade in sponges involves a heat-gated cation channel, abscisic acid, and cyclic ADP-ribose. Proc Natl Acad Sci U S A. 2001 Dec;98(26):14859-64. https://doi. org/10.1073/pnas.261448698

26. Puce S, Basile G, Bavestrello G, Bruzzone S, Cerrano C, Giovine M, et al. Abscisic acid signaling through cyclic ADP-ribose in hydroid regeneration. J Biol Chem. 2004 Sep;279(38):39783-8. https://doi. org/10.1074/jbc.M405348200

27. Hook V, Toneff T, Baylon S, Sei C. Differential activation of enkephalin, galanin, somatostatin, NPY, and VIP neuropeptide production by stimulators of protein kinases $A$ and $C$ in neuroendocrine chromaffin cells. Neuropeptides. 2008 Oct-Dec;42(5-6):503-11. https://doi. org/10.1016/j.npep.2008.05.001

28. Suh HW, Hudson PM, Hong JS. Expression of the proenkephalin A gene and [Met5]- enkephalin secretion induced by arachidonic acid in bovine adrenal medullary chromaffin cells: involvement of second messengers. J Neurochem. 1995 Feb;64(2):608-13. https://doi. org/10.1046/j.1471-4159.1995.64020608.x

29. Jiang YL, He XF, Shen YF, Yin XH, Du JY, Liang Yl, et al. Analgesic roles of peripheral intrinsic met-enkephalin and dynorphin A in long-lasting inflammatory pain induced by complete Freund's adjuvant in rats. Exp Ther Med. 2015 Jun;9(6): 2344-8. https://doi.org/10.3892/etm.2015.2407

30. Mudge AW, Leeman SE, Fischbach GD. Enkephalin inhibits release of substance P from sensory neurons in culture and decreases action potential duration. Proc Natl Acad Sci. 1979 Jan;76(1):526-30. https://doi.org/10.1073/pnas.76.1.526

31. Delgado M, Ganea D. Anti-inflammatory neuropeptides: a new class of endogenous immunoregulatory agents. Brain Behav Immun. 2008 Nov;22(8): 1146-51. https://doi.org/10.1016/j.bbi.2008.06.001

32. Song Y, Huang L-YM. Modulation of glycine receptor chloride channels by cAMP dependent protein kinase in spinal trigeminal neurons. Nature. 1990 Nov;348:242-5. https://doi.org/10.1038/348242a0

33. GuY, Huang LY. Cross $\square$ modulation of glycine $\square$ activated $\mathrm{Cl}$ - channels by protein kinase $\mathrm{C}$ and $\mathrm{CAMP} \square$ dependent protein kinase in the rat. J Physiol. 1998 Jan 15; 506(Pt 2):331-9. https://doi.org/10.1111/j.14697793.1998.331bw.x

34. Pidoplichko VI, Reymann KG. Abscisic acid potentiates NMDA-gated currents in hippocampal neurones. Neuroreport. $1994 \mathrm{Nov;5(1):2311-}$ 6. https://doi.org/10.1097/00001756-199411000-00026

35. Kumar S, Ren Q, Beckley JH, O'Buckley TK, Gigante ED, Santerre $J \mathrm{~L}$, et al. Ethanol Activation of Protein Kinase A Regulates GABA(A) Receptor Subunit Expression in the Cerebral Cortex and Contributes to Ethanol-Induced Hypnosis. Front Neurosci. 2012 Ape;6:44. https:// doi.org/10.3389/fnins.2012.00044 
36. Chen JT, Guo D, Campanelli D, Frattini F, Mayer F, Zhou L, et al. Presynaptic GABAergic inhibition regulated by BDNF contributes to neuropathic pain induction. Nat Commun. 2014 Oct;5:5331. https:// doi.org/10.1038/ncomms6331

37. Soti M,Abbasnejad M, Kooshki R, Esmaeili-Mahani S. Central microinjection of phytohormone abscisic acid changes feeding behavior, decreases body weight, and reduces brain oxidative stress in rats. Nutr Neurosci. 2018 Feb;22(10):679-87.https://doi.org/10.1080/1028415X.2018.1431093
38. Gårdmark M, Höglund AU, Hammarlund-Udenaes M. Aspects on Tail-Flick, Hot-Plate and Electrical Stimulation Tests for Morphine Antinociception. Pharmacol Toxicol. 1998 Dec;83(6):252-8. https://doi.org/10.1111/j.1600-0773.1998. tb01478.x

39. Mulder GB, Pritchett K. Rodent analgesiometry: the hot plate, tail flick and Von Frey hairs. J Am Assoc Lab Anim Sci. 2004 May;43(3):54-5 